\title{
Exploring Native and Non-Native EFL Teachers' Pedagogical Practices Related to Culture in Classroom Settings
}

\author{
Love Omolola Dabby and Meryem Akçayoğlu
}

\begin{abstract}
Culture is a vital part of EFL teaching, yet many EFL teachers are often faced with the challenge of incorporating culture into their teaching. The study attempts to describe how native and non-native EFL teachers position culture in teaching, also details which pedagogic strategy teachers use to impact culture while teaching. The study aimed to raise teachers' awareness of the relevance of cross-cultural teaching in practice for a better result of EFL cultural competence. The data was gathered from EFL teachers of different nationalities via a semi-structured interview with both native and non-native EFL teachers at a private school in Adana Turkey. Data was also collected through questionnaires. This study indicates that many EFL teachers are aware of culture's importance while some are aware of it to some extent. Findings from this study support previous research by providing contributions to the fields of pedagogic strategies and teaching culture in foreign language classes.
\end{abstract}

Keywords-Culture, foreign language teaching, language teaching methodology, language proficiency. Non-native teachers, teaching style.

1 This study involves preliminary findings of the MA thesis being supervised by Dr. Akçayoğlu

\section{INTRODUCTION}

Today, people all around the world emphasize and acknowledge the usefulness and importance of English as a global language, and many people learn it for various purpose. Some of these purposes include preparing for a career, in most cases, to study abroad or to make friends from other countries and also to do business worldwide. These reasons to have contributed to the dramatic increase in the number of people interested in learning English on a global scale. Therefore, this has brought a rise also in demand for English language teachers. Since most of the people willing to learn English for various purposes live in the places where English is being

Love Omolola Dabby (Author)

Cukurova University

Turkey

Meryem Akcayoglu(Author)

Cukurova University

Turkey tutored as a second or as a foreign language, most times, the teachers also come from these regions. There have been eternal questions raised about these teachers' language competence, pedagogical methods, and cultural orientation. Worldwide the English language as gained ground and became an international language for so long. It has been taught either as a foreign language or a second language in many countries. Ahmad (2005) explains and identifies four typical teaching concepts; he expresses teaching as labour, as a profession as craft, and as art. He classified teachers as reformers and human engineers (p.74). In Turkey, where English is learned-taught as a foreign language, many English teachers come from their own home country where the majority of them have received training to become EFL teachers. While also, many have gone to pursue a higher degree abroad, especially in an Englishspeaking country. Regardless of the numerous and inconclusive definition of native and non-native teachers in teaching the English language, foreign teachers with English speaking background are preferred as authentic linguistic and cultural representatives of EFL (Nayar, 1997).

Educating students in a foreign language stands as a challenge due to the language's technicalities and complexity. Like other school subjects in school, the foreign language is not confined to a particular domain or structure; instead, they are tasked with students' developmental skills in speaking, reading, listening, and writing. One common trend amongst many EFL teachers is the preference of linguistic forms while teaching, thereby subduing English language structures in their interactive and communicative contexts. By doing so, this creates issues of imbalance between linguistic and cultural elements because culture has often been relegated to the sidelines.

EFL teachers have increasingly understood teaching foreign language is not all about language skills, as cultural elements are also key to fully be competent in a language. The significance of cultural integration into language teaching is universally acknowledge and have generated prominent changes in the foreign language teaching (Arcagök \& Yımaz, 2020; Chau \& Truong, 2019; Kunanbayeva, 2013).

Integrating culture into EFL classroom is not only a superb supplement, but it is an inseparable part of culture and language process. This is because the framework through 
which language is interpreted comes from a cultural context. Even with the cordial relationship between culture and language, many EFL teachers still find it challenging to incorporate culture into their teaching methods considering the fact that many of them have the desire to teach culture. However, those desires face many challenges, one of which is the lack of a clear understanding of what culture means. Another challenge could be instructional time allocated to teaching culture because they explicitly focus on improving the students' linguistic competency. Improvising culture in the EFL classroom is one of the significant struggles of many teachers, both native and non-native. A majority o teachers desire to teach culture (Klein, 2004; Ryan, 1994), but they cannot due to several reasons. Lack of a clear definition of "culture" is one of the significant struggles many EFL teachers go through to fulfil those desires (Brooks, 1968). The issue of instructional time allocated to culture is also what many teachers claim of not having, as most of the time is allocated to the development of students' linguistic competency, instead (Byrd, 2011; Seelye, 1997). The method of teaching culture may also be one issues the teachers are unsure of, or some also may find assessing culture that they have taught a big challenge (Byrd, 2011; Omaggio Hadley, 2001).

The past 20 years have brought about the increasing interest in analyzing and documenting teachers' perceptions, culture, understanding, and knowledge (Clark and Peterson 1986; Cater 1990; Pajares 1992; Elbaz 1991). Every individual has a specific style of thinking and translations; this could be attributed to that personal background and culture, which is seen as an influencer to the individual day to day activities. In the concept of education, the teachers stand in the middle of the park (learning and the students).

Murphy (2005, p. 14) emphasized teachers' importance as those that influence both students and adults in the school setting. There is a need for various teaching methods and style in others to solve classroom problems and enthusiasm for acquiring new knowledge.

When it comes to EFL teaching, the importance of culture cannot be overemphasized. The role culture plays in the classroom determines, in most cases, the way and manner EFL teachers transfer knowledge to the students. It is generally accepted in EFL literature that teaching a language is also the teaching of culture. Various countries have their own various culture - moreover, these cultures feature how they are perceived and translated into knowledge.

According to Jarvis (2004), teaching style "includes the implementation of philosophy; it contains evidence of belief about values related to and attitudes towards all the elements of the teaching-learning exchange" (p. 40). This indicates all of the teachers' knowledge transfers techniques, approaches and activities employed in a specific subject in the classroom (Cooper, 2001). In other words, the teachers' teaching methods represent the teachers' behaviour as they teach in the classroom. Teaching a culture mirrors teachers' thoughts, culture, and the proceeding in which those thoughts are implanted. Also, the teachers' teaching styles could be influenced by their cultural perceptions.

There are unique characteristics found in English language teaching structure, and these characteristics are what differentiate English from other subjects in schools. The English language involves transmitting acquired knowledge and belief that is socially and culturally related. Teachers of other subjects can only boast of what they know, and they can only be proficient in their subject matters, but not by their characteristics. It is a different case for English language teachers because they seem to encounter various situations. The ideology that being able to speak the English language naturally means you can teach English is wrong, according to the hiring policy of English language teachers, "non-native speakers need not apply." This brought about a negative image of non-native speakers as less qualified language teachers and perpetuates the mightiness of native speakers for teaching a language (Walelign, 1986).

\section{The PURPose OF THE STUdy}

In this study, we aimed

- To examine any possible effects of culture in EFL teacher's teaching strategies in the classroom.

- To help raise teachers' awareness of the relevance of cross-cultural teaching in practice for a better result of competence.

- To provide theoretical contributions to the research areas of pedagogic strategies and teaching culture.

- To provide examples and samples that can be adapted and applied by EFL teachers and to enhance culture learning of their students in the classroom.

The validity and usefulness of cross-cultural teaching strategies for effective classroom practice in Turkish schools and their English language proficiency have been discussed in various English language fields.

Based on investigating EFL teachers' pedagogic strategies and how they relate to their culture through cross-culture strategies and how they apply it in Turkish EFL classroom, qualitative method was deemed appropriate for the findings in the research using analysis and evaluation data gathered from EFL teachers through a semi-structured interview. This method provides an in depth insight into how EFL teachers apply various pedagogic strategies in different classroom practices concerning culture.

\section{BACKGROUND OF THE STUDY}

Culture occupies a significant space when it comes to foreign language teaching and learning. According to Marcal (2010), learners need to acquire knowledge in foreign language culture to understand viewpoints, get ready for personal engagement with a foreign culture, and set the language into context. Thanasoulas (2001) stated that culture could improve the learners' communicative competence making them to have empathy and respect for different 
language as well as encourage objectivity and cultural perceptions. Additionally, culture is regarded as communicative competence (Hymes, 1972), or considered the 5th language skill. Therefore, it is crucial to integrate culture into language teaching which not only develops leaners' abilities to commutate, but also they get to use the language productively and appropriately in several contexts. Svarstad (2020) suggests that “... English teachers must be offered professional development in Cultural studies providing them with pedagogical tools to carry out cultural analysis and to develop a metalanguage about cultural analysis they can use in classroom dialogues." This is indeed a much needed component in teaching English as a foreign language domain for it has the potential of empowering students' cultural competence which will in return contribute to deepen their linguistic competences.

Due to the complexity of the connection between language and culture and also the applications of culture in language teaching, various scholars have proposed embedment of culture into foreign language teaching. Nevertheless, in practice, whether cultural elements can be incorporated into foreign language classroom and how is still a question. Research regarding culture embedment in foreign language classroom, most importantly on the EFL teachers' perceptions of culture integration into EFL classroom still remains to be explored. Therefore, investigation on culture integration into EFL classes is practical and essential. Findings from this study may confer to the theoretical research gap in foreign language teaching and culture.

The primary purpose of this study is to explore the EFL teachers teaching methods and styles and relating them to the cultural perceptive of both native and foreign (non-native) teachers in Turkish schools. Knowing that culture is an essential tool in EFL teaching, and yet a lot of EFL teachers' finding it challenging to incorporate in their practice, calls for more investigation. That brings us to the question of what is taking place in EFL classes regarding culture integration today. The following the research questions were raised to investigate:

1. What are foreign EFL teachers' and Turkish EFL teachers' perceptions of culture?

2. Through which methods is culture taught in EFL classroom by foreign EFL teachers and Turkish EFL teachers?

A total of 50 EFL teachers, 28 females and 22 males, took part in a semi-structured interview conducted through videotaped online video calls due to Covid-19 pandemic restrictions. 25 participants, 8 females and 17 males, are foreign EFL teachers while 25 Turkish EFL teachers are comprised of 20 females and 5 males. Data was collected in the summer of 2020 and 190 EFL teachers in Turkey voluntarily joined the research by giving their responses to online questionnaires. Out of 190 participants 117 are Turkish
EFL teachers and 71 are foreign EFL teachers; two teachers didn't indicate gender.

\section{MAIN FINDINGS}

This study seeks an understanding of how culture is being incorporated into the EFL classroom in Turkish schools. It is therefore, imperative to report what both Native and nonnative teachers believe culture is.

\section{A. Research question 1}

What are foreign EFL teachers' and Turkish EFL teachers' perceptions of culture?

One of the questions in the interview was "What is "culture?" There were quite mixed responses; some were shorter and simpler, for example: "culture to me I think, is the way of life of people, also beliefs and religion" while many other descriptions were longer and more complex. The definition of culture can come in various ways, but the majority of the respondents perceive culture as "a way of life."

\section{- Some excerpts from Foreign EFL participants}

P9: Well, I would say that culture is like the way of life of a group of people, like what they believe, what they value, I think their everyday life, their philosophy and outlook towards life in general that what I would say is the culture.

P6: It can be defined as, you know, ideas, knowledge, behavior, beliefs, values, morals, law of the city, customs and other other stuff.

P19: Well, there are so many definitions about culture, but if you really want my perspective about culture, culture is simply uhm.. something that has to do with the lifestyle of ,you know, a particular set of people, ugh what they go about, you know certain practices they do to be able to eh.. evolve within their community, so basically it is eh something that has to do with eh..

\section{- Some excerpts from Turkish EFL participants}

P8: For me, culture is not the same as we can define it like ten years ago; culture is the element that belongs to a group of people, living in the same environment. We can say that we are Turkish and we share similar beliefs and ideas. That's what culture means to me.

P2: Actually, I think culture is a way of life of a group of people, their behavior, and their belief. That is a symbol of that exact culture. It is transmission from one generation to the next generation.

P7: Culture is the social behavior of a person and how they live their lives and according to the place that they grow up. This is culture to me.

As it is clear from the excerpts, definition and perceptions of culture can, obviously, be described in various ways, but the majority of the respondents, both native and non-native teachers, agreed that culture is closely interconnected with language teaching and also is a very important component. All 
50 interviewed participants considered themselves to be knowledgeable about the English culture. Data collected from the interview questions were coded and categorized in the frequency of appearances. Interviewed participants valued beliefs, customs and traditions, product, attitudes and belief, history and behaviors as the most essential elements of culture.

\section{B. Research question 2}

Through which methods is culture taught in EFL classroom by foreign EFL teachers and Turkish EFL teachers?

During teaching in the classroom, teachers utilize various resources and methods to pass down knowledge to the students. As reported by the participants, one standard method frequently used in the classroom is the use of media, role play, and interactive sections.

\section{- Some excerpts from Foreign EFL participants}

P2: I think the best way to teach culture is ehm... to try to help students to be open to that culture, like open their eyes, try to be like eh comprehensive about other traditions, other cultures, other habits, other things that are different from their own culture

P8: Okay, sometimes I do speaking activities with my students and I can choose ehm a topic like culture, so before I do that, I show them some videos from my own country, I am from Ghana, so I show them some facts about Ghana, some touristic places, some food, our traditional clothing/costumes, everything about them. So I use videos and sometimes I bring my own, I have some African cloths at home, so I bring them to the classroom and I show them to my students. And sometimes also use pictures if I don't have the real material, so this is how I teach culture. I do that through speaking activities.

P5: Like is said before, you have to model it and they have to practice; you teach them what they are supposed to do and they have to practice and you have to be consistent. You have to keep doing it; you have to keep speaking the language, acting the way you want them, yes that's the way they learn.

\section{- Some excerpts from Turkish EFL participants}

P4: Like I said, the posters, the videos, and TV series from the UK. Because I am teaching English and I wish my students to see how they live, what they do in their various lives. And I try to get some poster, some videos, maybe some parts of the TV series to the classroom. To show them, okay you are trying to learn this language, these are the people who live in the UK. See their accent is each different from one another?

P10: By comparing two cultures. The students already live in a culture, so I try to have them know that they are living in a culture and that there are cultures different from theirs all around the world. So I firstly compare the two cultures in some aspects that are similar.

P5: Okay, it is generally related to situations based uhm for example, when I teach expressions of permissions like 'can' or 'may'. If you are talking to your boss in America, you have to use 'may' and you have to use 'can' if you are talking to your friends. I integrate it with the things that they learn, like grammar or vocabulary and the like. I exemplify it in some real-like situations.

\section{V.CONCLUSION}

This study has explored native and non-native teachers' perceptions of culture as it pertains to the field of English language teaching. From the result of the study, it can be evident that (1) the teachers' participant are fully aware of the definition of culture and strongly believe that culture plays a vital role in EFL classroom, giving the student the ability to achieve both linguistic and communicative competence; (2) teachers tend to develop and use their own materials and also their prior knowledge while teaching culture in the classroom; (3) teachers present students with cultural information and develop students cultural interpretation; (4)teachers use various teaching activities for culture embedment; (5) the teachers' aims at culture integration is that students have a full understanding and also express their own culture. In summary, although there is a need to investigate culture further as it pertains to EFL teaching, this study contributes to the current knowledge of teachers' perceptions concerning culture, the method teachers' use in integrating culture into their classes and how much cultural instruction is given in the EFL classroom.

\section{IMPLICATIONS AND LIMITATIONS OF THE STUDY}

As regards the incorporations and implementation of culture in the EFL classroom, the listed theme from this study can bring about thinking and practice in the profession:

- The inclusions of culture should be seen as a necessity for adequate language instructions

- Cultural teaching should be made meaningful through adequate preparations and standard assessment

One significant limitation of this study is that this research was conducted in only one private school in Turkey, and the questionnaire was restricted to EFL teachers only. If it can be conducted in more schools and in other countries, the results could then be more generalized. It is also possible that participants who took part in the study might be more interested in culture, teaching methods, or research, therefore, the participants may not be a representative sample if these external variables are considered.

\section{ACKNOWLEDGMENT}

This study is supported by the Scientific Research Projects Department of Cukurova University, (BABSIS) with Project code: SYL-2020-12866.

\section{REFERENCES}

[1] Ahmad, G. P. (2005). A model of in-service Training for University Teachers. Gomal University, Journal of Research, 21, 74-7 
[2] Arcagök, S. \& Yımaz, C. (2020). Intercultural sensitivities: A mixed methods study with pre-service EFL teachers in Turkey. Issues in Educational Research, $\quad 30(1), 18$. http://www.iier.org.au/iier30/arcagok.pdf

[3] Byrd, D. R., Hlas, A. C., Watze, J., \& Valencia, M. F. M. (2011). An examination of culture knowledge: A study of L2 teachers' and teacher educators' beliefs and practices. Foreign Language Annals, 44, 4-39. https://doi.org/10.1111/j.1944-9720.2011.01117.x

[4] Chau, T. H. H. \& Truong, V. (2019). The integration of intercultural education into teaching English: What Vietnamese teachers do and say. International Journal of Instruction, 12(1), 441-456. https://doi.org/10.29333/iji.2019.12129a

[5] Clark, C. M., \& Peterson, P. L. (1986). Teachers' thought processes. In M.W. Wittock (Ed.), Handbook of Research on Teaching (pp.255296). New York: Macmillan.

[6] Cooper, T. C. (2001). Foreign language style and personality. Foreign Language Annals, 34, 301-16. http://dx.doi.org/10.1111/j.19449720.2001.tb02062.x

[7] Elbaz, F. (1991). Research on teachers' knowledge: The evolution of a discourse. Journal of Curriculum Studies, 23, 1-19. http://dx.doi.org/10.1080/0022027910230101

[8] Hymes, D. H. (1972). On communicative competence. In J.B. Pride and J. Holmes (Eds.), Sociolinguistics: Select- ed Readings (pp. 269293). Harmondsworth: Penguin.

[9] Jarvis, P. (2004). Adult education and lifelong learning: Theory and practice. London: Routledge Falmer. https://doi.org/10.4324/9780203561560

[10] Kachru, B. (1996). The paradigms of marginality. World Englishes, 15(3), 241-255. https://doi.org/10.1111/j.1467-971X.1996.tb00112.x

[11] Klein, F. M. (2004). Culture in the foreign language classroom: teachers' beliefs, opportunities and practice. (Unpublished doctoral dissertation). University of Minnesota, Minneapolis.

[12] Kunanbayeva, S. S. (2013). The modernization of foreign language education: The linguocultural- communicative approach. United Kingdom: Hertfordshire Press. https://www.academia.edu/21856191

[13] Lone Krogsgaard Svarstad (2020) Cultural studies and intersectionality in English language education: exploring students' engagement in issues of celebrity, identity, gender and sexuality, The Language Learning Journal, DOI: 10.1080/09571736.2019.1709885

[14] Marcal, M. (2010). The Integration of culture into foreign language classrooms. (Unpublished Master's Theses and Honors Projects). The College at Brockport: State University of New York.

[15] Murphy, J. F. (2005). Connecting teacher leadership and school and school improvement; London: Crawin Press Inc.

[16] Nayar, P. Bhasaran. (1997, September). ESL/EFL dichotomy today: Language politics or pragmatics?.TESOL Quarterly, 31(1), 9-37. https://doi.org/10.2307/3587973

[17] Omaggio Hadley, A. (2001). Teaching for cultural understanding. In Teaching Language in Context (3rd ed.). Boston, MA: Heinle \& Heinle. (pp. 345-389).

[18] Pajares, M. F. (1992). Teacher's beliefs and educational research: Cleaning up a messy construct. Review of Educational Research, 62(3), 307-332. https://doi.org/10.3102/00346543062003307

[19] Ryan, P. M. (1994). Foreign language teachers' perceptions of culture and the classroom: A case study. (Unpublished doctoral dissertation). University of Utah, Salt Lake City.

[20] Seelye, H. N. (1997). Forward. In P. R. Heusinkveld (Ed.), Pathways to Culture: Readings on Teaching Culture in the Foreign Language Class (xiii-xx). London, UK: Intercultural Press.

[21] Thanasoulas, D. (2001). The Importance of teaching culture in the foreign language classroom. Radical Pedagogy, 3(3), 1-25.

[22] Walelign, A. (1986). Non-native speakers need not apply. English Teaching Forum, 24(2), 40-41. 